\title{
Citizens United vs. FEC and Corporate Political Activism*
}

\author{
Rui Albuquerque \\ Boston College Carroll School of Management \\ CEPR, ECGI \\ Zicheng Lei \\ Surrey Business School, University of Surrey \\ Jörg Rocholl \\ ESMT Berlin, CEPR, and ECGI \\ Chendi Zhang \\ University of Exeter Business School
}

September 2019

\begin{abstract}
This paper analyzes the effect that the U.S. Supreme Court's landmark decision on Citizens United vs. FEC had on corporate political activism. The decision opened the door for corporate treasuries to engage in independent political spending. Politically connected firms have lower announcement returns at the ruling than non-connected firms. The estimates suggest that the value of a political connection decreases by $\$ 6.9$ million. To evaluate the effect of Citizens United on corporate political activism, we explore the fact that Citizens United also lifts bans on independent political spending in states where such bans existed. After the ruling, firms headquartered in states where bans are lifted have fewer state-level connections relative to firms in other states. Overall, our evidence supports the hypothesis that independent political spending crowds out political connections. We do not find any significant crowding-out effects of independent political expenditures on lobbying activity, executive contributions, and political action committees (PAC) contributions.
\end{abstract}

Keywords: Corporate political activism, political connections, Citizens United, stock returns.

\footnotetext{
* We would like to thank the comments from two anonymous referees, Paul Calluzzo, John Coates, Miguel Ferreira, Chen Lin, Pedro Raposo, Morten Sorensen, and Timothy Werner, conference participants at NFA 2016, CICF 2016, Paris December Finance Meeting 2016, IFABS 2016, and seminar participants at Singapore Management University, Hong Kong University of Science and Technology, University of Hong Kong, University of Birmingham, University of Piraeus, University of Warwick, University of Surrey and Renmin University of China. We thank Ana Albuquerque for providing us with estimates of CEO excess pay. Albuquerque acknowledges financial support by the Portuguese Foundation for Science and Technology-FCT under grant PTDC/IIM-FIN/2977/2014. The usual disclaimer applies.
} 


\section{Introduction}

The U.S. Supreme Court's landmark decision on Citizens United vs. Federal Election Commission $(C U)$ in January 2010 represents the most dramatic change in corporate campaign financing since the Taft-Hartley Act of 1947. It asserts for the first time that corporations benefit from First Amendment protection regarding freedom of speech. ${ }^{1}$ In practice, the ruling lifts prior bans on corporations to use their treasuries to advocate in favor or against a political candidate on an election, known as independent expenditures on express advocacy. $C U$ had an immediate and profound impact on campaign financing with independent expenditures in presidential cycles increasing from $\$ 143$ million in 2008 before the ruling, to over \$1 billion in the 2012 and $\$ 1.4$ billion in 2016 after the ruling (Centre for Responsive Politics, 2019). We study the effects on corporate political activism that occur with $C U$. Specifically, we are interested in exploring how the $C U$ ruling, and the new ability to engage in political activism through independent expenditures affect the value of existing forms of corporate political activism.

Issacharoff and Karlan (1999) hypothesize that campaign finance money is like a hydraulic system. This hypothesis implies a substitution or crowding-out effect where political money "never really disappears into thin air" (p. 1708), rather it "has to go somewhere" as regulation opens up new doors. On the other hand, there is evidence suggesting that "interest groups who engage in PAC [(political action committees)] contributions do not lobby and that most interest groups who lobby do not engage in PAC contributions" (Lake, 2015, p. 87). This evidence paints a view of segmentation on the various forms of political influence. The goal of this paper is to provide evidence on this debate by answering the quest set by Issacharoff and Karlan that "understanding

\footnotetext{
${ }^{1}$ Citizens United, Appellant vs. Federal Election Commission, 558 U.S. (docket nos. 08-205) decided 1/21/2010. Werner (2011) provides an overview of the antecedents of $C U$ and of the ruling itself.
} 
why [political money] flows where it does and what functions it serves when it gets there requires thinking about the system as a whole" (p. 1708).

As connections, lobbying as well as PAC and executive contributions all serve the same purpose, though with different focus and efficacy. One might expect that firms engage in several of these at the same time (e.g., Akey, 2015, Ansolabehere et al., 2002, Austen-Smith, 1995, Briffault, 2008, Lake, 2015, and Wright, 1996). However, observing that firms engage in more than one type of political activism says little about the complementarity, substitutability, or segmentation across these inputs, just as the degree of input substitutability in a production function cannot be ascertained simply by observing that firms use both labor and capital.

We use $C U$ as an exogenous identification shock to substitutability as the Supreme Court decision was largely unanticipated (it was also a close 5-4 decision). We study the announcement returns to firms that are politically active before $C U$. We identify firms that are politically active by using data on political connections (by the firm's top executives, board members and senior managers), lobbying expenditures, and contributions by both PAC and top executives. Our event study is akin to a difference-in-differences design: the left-hand-side variable is the change in price from before the $C U$ decision to after the $C U$ decision (i.e., the cumulative abnormal return) and the right-hand-side variable of interest is the pre-event level of activism, which is a continuous treatment variable that exploits cross-sectional variation (see Duflo, 2001; Florens et al., 2008).

We find that stock market returns at the announcement are negatively associated with the level of political connections in a firm, but do not observe any effect on firms that engage in other dimensions of political activism, such as lobbying, PAC, or executive contributions. The negative announcement return implies a loss in value of one political connection of \$6.9 million for a firm with average market capitalization. We attribute the decline in the value of political connections 
to a crowding-out effect from independent political spending. We do not interpret this evidence as saying that political connections are no longer valuable to corporations (Goldman, Rocholl, and So, 2009, Fisman, 2001, and Faccio, 2006, provide evidence on the value of political connections). Instead, some of the value of political connections appears to be subsumed by the existence of a new form of political activism.

The crowding-out hypothesis predicts that the observed market reaction is accompanied by changes in political activism after $C U$, as firms substitute away from less valuable forms of political activism. We regress the level of activism on a dummy variable that describes pre- and post- $C U$ decision periods. However, without another source of heterogeneity across firms, we cannot adequately control for time-series changes in connections caused by unobserved concurrent events, and therefore, endogeneity issues are potentially severe. We explore the fact that twentythree states had state-election bans on independent political expenditures by corporations before $C U$, besides the federal-election ban on independent political spending that affected all states. ${ }^{2}$ The decision in $C U$ overrules all bans, including state-election bans, and gives rise to a crosssectional difference that allows the identification of the effect of independent political spending on corporate political activism based on company-headquarter state. Corporations headquartered in ban states form the treatment group, while corporations in no-ban states form the control group (see also Spencer and Wood, 2014). This difference-in-differences analysis allows us to control for any events, concurrent to $C U$ that may also affect how firms change their political activism. One limitation of this analysis is that the treatment effects focus on only state-level dimensions of

\footnotetext{
${ }^{2}$ State bans had been ruled constitutional by the U.S. Supreme Court in 1990 in Austin vs. Michigan Chamber of Commerce. Austin, Michigan Secretary of State, et al. vs. Michigan Chamber of Commerce, 494 U.S. 652 (1990).
} 
political activism. Therefore, we remain cautious in the interpretation of any potential impact of $C U$ on national-level aspects of political activism.

We find that firms have $13.6 \%$ fewer state-level political connections after $C U$ if their headquarters locate in ban states relative to those firms that locate in no-ban states. This finding is consistent with the hypothesis that independent political expenditures crowd out political connections after $C U$. Consistent with not having found any announcement return effect on firms that engage in other dimensions of political activism, such as lobbying, state-level PAC, or executive contributions, we find no changes in those dimensions before and after $C U$ for states with bans versus states without bans on independent spending before $C U$. We also find no evidence that national-level connections responded differently after $C U$ for states with bans and states without bans.

To summarize, we find evidence of crowding out of political connections, but no evidence of crowding out along the other dimensions of corporate political activism: lobbying, PAC, and executive contributions. There are several potential explanations for why not all forms of political activism respond to $C U$. Lobbying is generally viewed as issue-specific, calling for specific legislation or regulation, which may explain less of a crowding-out effect. Briffault (2008) argues that the law is less restrictive on lobbying versus PAC contributions as it recognizes a special function to the former for both corporations and unions to organize grassroots in helping the legislator. Likewise, Bertrand et al. (2014) also argue for a specific role for lobbying. ${ }^{3}$ PAC contributions are not exclusively under the control of management in that unions not only help

\footnotetext{
${ }^{3}$ Some authors find evidence that lobbying is more efficient in some settings than connections. Correia (2014) documents that directly lobbying the SEC is more effective than having executives with connections to the SEC in reducing enforcement costs faced by firms. Blau et al. (2013) document that lobbying was more efficient in receiving money from the Troubled Asset Relief Program than connections. Bertrand et al. (2014) argue that lobbying activities are particularly suited as a vehicle to provide issue-specific information to regulators and politicians.
} 
fund them but also help direct the funds. Thus, PAC contributions may also experience limited or no crowding out. Like independent expenditures, executive contributions are under the control of management and promote express or candidate advocacy; executive contributions are therefore likely candidates for crowding out. However, the fact that executive contributions have low legal limits, do not involve the corporate treasury, and are tied to the manager rather than to the firm, may limit crowding out. Similar to independent expenditures, political connections are strictly under the control of management and can be used for general influence. These two characteristics make political connections a close substitute for independent political spending in the pursuit of political activism.

Next, we examine the heterogeneity of the crowding-out effect on connections based on who is the connected agent. We define Executive Connection if the classification of the connected individual includes $\mathrm{CEO}, \mathrm{CFO}$, or COO. We define Board Connection if the classification of the connected individual includes independent director, director, or independent/deputy chairman. We define Other Connection if the classification of the connected individual includes senior VP, division/regional president, or general manager. Our results indicate that the loss of value in connections occurs mostly in the Other Connection category. This evidence is consistent with Faccio, Masulis, and McConnell (2006) who show that political connections via top executives appear to be more effective, and therefore less substitutable.

Finally, we investigate the heterogeneous effects based on industry attributes by examining the relationship between political activism and firm value separately for industries with high or low reliance on the political sector. We find that regulated industries display a positive and significant market reaction to $C U$, which is consistent with Burns and Jindra (2014). They argue that regulated industries have more significant interaction with the government and may benefit more from 
having more avenues to advance their agendas. In addition to this result, we show that firms with high connections in non-regulated industries experience negative announcement returns, whereas connections appear not to affect announcement returns in regulated industries. This result is consistent with Faccio $(2006,2010)$ who suggests that firms in the regulated industries are more likely to harness the benefits from political and government connections, which become less substitutable than connections in non-regulated industries.

In robustness analysis, we consider the possibility that the announcement returns are driven by other information events occurring on the day of the ruling. The main other such event is the announcement by President Obama publicly endorsing the Volcker rule. The results are unchanged if we exclude financial firms. We also perform placebo tests by repeating our tests with data two weeks before and also two weeks after the date when the $C U$ decision is announced. We find no statistically significant effect on announcement returns at the placebo dates for firms politically active through either connection, lobbying, PAC, or executive contributions. We also include a vast array of control variables, including state-level political competition proxies, dependency on the government as a top customer, and others. Our results on the crowding-out effect over political connections remain.

Our paper contributes to the evidence on the value of corporate political connections. There is an extensive literature documenting that political connections add value to the firm (see Goldman, Rocholl, and So, 2009, for evidence in the U.S., and international evidence see Fisman, 2001, Faccio, 2006, Bunkanwanicha and Wiwattanakantang, 2009, Amore and Bennedsen, 2013, and Schoenherr, 2019). Many papers have provided evidence on the sources of value from political connections including the ability to access outside funding (Khwaja and Mian, 2005, and Leuz and Oberholzer-Gee, 2006), the likelihood of being bailed out or of facing less enforcement (Faccio, 
Masulis, and McConnell, 2006, and Correia, 2014), the subsidies gained in the event of financial crises (Johnson and Mitton, 2003; Duchin and Sosyura, 2012; Kostovetsky, 2015; and Acemoglu, Johnson, Kermani, Kwak, and Mitton, 2016) and in obtaining procurement contracts (Goldman, Rocholl, and So, 2013). Complementing this literature, we show a crowding-out effect on political connections from a new form of political activism.

Our paper is also related to the work on the effects of $C U$. We are the first paper to explore the impact of $C U$ on the value of political connections, arguably the closest substitute to independent political spending. Consistent with our results, Spencer and Wood (2014) find an increase in independent expenditures in state elections for states with prior bans on independent political spending. Werner (2011), like us, finds no evidence of market reaction to $C U$ for firms with lobbying activity and political action committee (PAC) contributions. Werner (2011) also finds no evidence of market reaction for firms with procurement contracts. Coates (2012) finds increased PAC contributions and lobbying expenditures after $C U$ for politically active, unregulated firms. Our difference-in-differences result of no change in PAC contributions (for state-level elections) in ban states versus no ban states after $C U$ suggests that the finding in Coates is due to other concurrent events that lead to a generalized increase in PAC contributions. Newton and Uysal (2013) find an adverse market reaction around the announcement of $C U$ for firms with high levels of PAC contributions.

Finally, our paper contributes to the literature on corporate governance. There is a clear sense that political activism can be beneficial to shareholders and plenty of evidence shows that connections are valuable. However, managers can play the game of political activism for private 
benefit (Bebchuk and Jackson, 2012). ${ }^{4}$ Since the $C U$ ruling, there has been a heated policy debate on whether the SEC should issue regulations that require public companies to disclose their political expenditure. ${ }^{5}$ Little is known of $C U^{\text {'s }}$ effects on corporate political activism. To our knowledge, we are the first paper to show that, in the absence of disclosure requirements, independent expenditures can substitute for political connections but not for lobbying or PAC contributions. Our findings suggest that the discretion that management may have with independent expenditures and political connections does not carry to lobbying or PAC contributions. Understanding these differences may help inform the current debate.

The rest of the paper is organized as follows. Section II presents the data, and Section III gives our main results. Section IV discusses robustness issues and Section V concludes.

\section{Data}

We collect data to conduct two main tests. The first is an event study of the cumulative abnormal returns around the Supreme Court's decision for which we need controls measured as of 2009. The second is a difference-in-differences analysis, and we use data from 2007 to 2012.

\section{A. Corporate Political Activism and Stock Returns Around the Announcement}

\footnotetext{
${ }^{4}$ In its proxy voting recommendations on "Political Contributions, Lobbying Reporting \& Disclosure," Institutional Shareholder Services (2019, p. 58) writes "While political contributions, lobbying and other corporate political activity can benefit the strategic interests of a company, it is important that accountability mechanisms are in place to ensure that monies disbursed in support of political objectives actually generate identifiable returns on shareholder wealth."

${ }^{5}$ In December 2015, Congress adopted a budget agreement that included a provision preventing the SEC from issuing a corporate political disclosure rule (Bebchuk and Jackson, 2015). In February 2019, a new bill named as "Corporate Political Disclosure Act of 2019" was introduced to Congress. It directs the SEC to issue regulations on political spending disclosure, although doubts remain if it can be passed by the Senate (Posner, 2019). In parallel to political moves on corporate disclosure, $C U$ appears to have awakened shareholders as well to these issues. Proxy Monitor reports that companies in the Fortune 250 saw a $150 \%$ increase in relevant shareholder proposals after $C U$ (Copland and O'Keefe, 2016), and Cohn et al. (2016) and Westcott (2013) report a jump in shareholder proposals regarding the disclosure of political spending.
} 
Our sample is based on firms in ExecuComp, which covers 1,830 listed firms in 2009. We obtain stock returns from the Center for Research in Securities Prices (CRSP) files and require that ExecuComp firms have available stock return data before and around January 21, 2010. We calculate the cumulative abnormal return (CAR) using the market model across several event windows, $(-1,1),(0,1),(-1,2)$ and $(-1,3)$, using the CRSP value-weighted market index as the benchmark, where January 21 is day 0 . CAR is expressed in percentage terms. The estimation period for the market model ends ten days before the announcement of $C U$, and we require a minimum (maximum) estimation period of 60 (505) days. ${ }^{6}$ The estimation period requirement reduces our sample to 1,748 firms. The accounting variables used as controls in the regressions are obtained from Compustat. These variables are winsorized at the levels of $1 \%$ and $99 \%$. Merging the abnormal return data with the accounting data results in a final sample of 1,722 firms.

We obtain several measures of corporate political activism. Corporate connections are measured using BoardEx. We collect CVs of corporate board members, top executives and senior managers from BoardEx, and produce a list of individuals who currently hold or previously have held a position in a government organization in the U.S. The number of political connections for each firm in any given year (Connection) is the number of executives, board members and senior managers of the firm with such positions in that year. To merge BoardEx with ExecuComp, we require firms to have valid identifiers such as tickers; when tickers are missing or incorrect from BoardEx, we manually match firms using firm names. Out of our sample of 1,722 firms from ExecuComp, 1,186 firms have non-zero political connections from BoardEx in 2009. For the remaining firms in our sample, we code connections as zero. Connections is a continuous treatment

\footnotetext{
${ }^{6}$ Results (untabulated) are also similar if we use the market-adjusted returns to measure abnormal returns, i.e. raw return in excess of the market return.
} 
variable that exploits cross-sectional variation in activism (see Duflo, 2001; Florens et al, 2008). In a continuous treatment variable, the differential (and continuous) exposure to the treatment is what captures unobserved variation from concurrent events. We give the same interpretation to the zeros in the other measures of political activism described below.

Firms have political connections with different levels of government, and we further divide connections into national, state, and local using information from the organization's name. We define a government organization as a national one if its name includes any of the following terms: "Federal", "National", "US", "President" or "White House". We define a government organization as a state one if "state", "senate" (in the state legislature) or any name of the 50 states in America is included in the organization's name. ${ }^{7}$ Finally, we define a government organization as a local one if its name contains any of the following words: "City", "County", "Village", "Town" or "Corp". We manually check and categorize government organizations that do not contain any of these words.

Executive contribution data are obtained from individual political contributions data of the Federal Election Commission (FEC) for ten federal election cycles from 1991 to 2010. The FEC gives information on donors' names, employers, addresses, and sometimes their occupation. We match these data with ExecuComp data on names of company executives and their annual compensation information for 37,886 executives in 3,241 listed companies over 1991-2010. We develop an algorithm to conduct the match and visually check the results. The match is based on (i) last name (exact match), (ii) first name (allowing for variations, e.g. Rob vs. Robert), (iii) either

\footnotetext{
${ }^{7}$ If the name of the government organization contains "United States", it will be mistakenly categorized into the statelevel group under this classification. We then manually check these observations and define them as national. Similarly, if the name of the government organization contains "senate", it could include a senate in congress. To ensure accuracy, we also manually classify them as either a national or state government organization.
} 
employer names (including employment history) or (3-digit) zip codes. This leads to 269,618 matched contributions, by 16,747 executives in 3,019 firms from 1991 to 2010 . About $82 \%$ of matched results are based on employer names rather than zip codes. ${ }^{8}$ We then aggregate individual contributions to the firm level for our sample of 1,722 firms. For the event study analysis, we measure a firm's executives' political contributions in 2009 (Executive Contribution) by cumulating all past contributions made before the end of 2009 by current executives independently of their previous employment. ${ }^{9}$ For the difference-in-differences analysis, we use the current value of executive contributions for each firm and year from 2007 to 2012. Executive Contribution is set to zero for firms whose executives are not in the FEC data.

Lobbying data are obtained from the Center for Responsive Politics. Lobbying data are collected since 1998 for firms that spend more than $\$ 20,000$ on direct lobbying activities and are thus required by the Lobbying Disclosure Act of 1995 to file with the Senate Office of Public Records and the Clerk of the House of Representatives. We match these data to the ExecuComp sample by manually checking firm names. Among our sample of 1,722 firms from ExecuComp, 742 firms have non-zero lobbying expenditures in 2009. We code lobbying as zero for ExecuComp firms that never spend money on lobbying. For the event study analysis, we add up all past lobbying expenditures made before 2009 for each firm to calculate cumulative prior lobbying

\footnotetext{
${ }^{8}$ As a robustness check for the match, we check the occupation of matched donors. FEC has begun record occupation since 2001 and the coverage has improved over time. In 2010, 80\% of the matched donors have recorded occupation of 'executive', 'director', 'CEO', etc.

${ }^{9} \mathrm{We}$ also use another measure to aggregate individual contributions to the firm level. This measure tracks the firm: it sums up contributions made by both current and past executives, only if a contribution is made during the tenure as a top executive of the firm. We obtain similar results. The results discussed in the paper and not tabulated can be found in the paper's internet appendix.
} 
expenditures (Lobbying). In the difference-in-differences analysis, we use each firm's current value of lobbying expenditures for each year from 2007 to 2012.

Political contributions of firms' Political Action Committees to state elections are obtained from the National Institute on Money in State Politics. We match the contributions data to the ExecuComp sample by manually checking firm names. PAC Contribution for each firm in 2009 is the sum of all past contributions donated before the end of 2009. Out of our sample of 1,722 firms, 502 firms have non-zero PAC contributions in 2009. We code PAC contribution as zero for ExecuComp firms that never spend money on PAC contributions. For the difference-in-differences analysis, we use the current value of PAC contributions for each firm and year from 2007 to 2012.

\section{B. Corporate Governance Measures}

Following Gompers, Ishii, and Metrick (2003) and Bebchuk, Cohen, and Ferrell (2009), we use both G-Index and E-Index as corporate governance measures. Gompers, Ishii, and Metrick (2003) construct an equally-weighted index based on 24 governance provisions from the Investor Responsibility Research Center (IRRC). Bebchuk, Cohen, and Ferrell (2009) propose an index based on six of these provisions: staggered boards, limits to shareholder bylaw amendments, poison pills, golden parachutes, and supermajority requirements for charter amendments and mergers. Among our 1,722 firms, 1,429 firms have available data on G-Index and E-Index.

We use two additional measures of corporate governance. A firm where the CEO is also chairman of the board may have fewer mechanisms for supervising management. Hence, we use a dummy variable to capture whether a CEO is the Chairman of the Board (CEO Duality). We obtain positions of executives from RiskMetrics and manually check whether the CEO held the position of chairman of the board as of the end of each year. Further, poor governance may drive 
CEO entrenchment and lead to excess CEO pay. We follow Larcker, Ormazabal, and Taylor (2011) and measure excess pay (Excesspay) using ExecuComp data as the difference between CEO compensation and the median compensation of a set of peer firms in the same industry and of similar size as that of the firm. More specifically, Excesspay is calculated as the logarithm of total compensation (variable TDC1 from ExecuComp) for the CEO minus the logarithm of the median total annual pay for all remaining firms on ExecuComp that are in the same Fama and French (1997) 12-industry group and size quintile of the firm for that year. The definitions and data sources of the control variables can be found in the appendix. Table 1 shows the summary statistics for all variables for the 2009 cross-section of firms.

[Table 1 about here]

\section{Empirical Results}

\section{A. Political Activism and Firm Value}

In this section, we examine the effect of Citizens United vs. FEC for firms with different levels of political activism. Our main test estimates the stock market response to the announcement of the ruling for firms with existing political activism relative to firms with no political activism. This event study is akin to a difference-in-differences design where the left-hand-side variable is the cumulative abnormal return from before the $C U$ decision to after the $C U$ decision (i.e., the change in price) and the right-hand-side variable of interest is the pre-event level of activism. Table 2 presents regression results on the relationship between political activism and firm cumulative abnormal returns around the announcement of $C U$, after controlling for firm and industry characteristics. We measure cumulative returns over different event windows around January 21, 
2010. Columns (1) through (4) of both Panels A and B display the results for event windows of $(-1,+1),(0,+1),(-1,+2)$, and $(-1,+3)$. We add control variables that are suggested in the literature, including three-digit SIC industry dummies. Standard errors are clustered by industry. The reason to cluster by industry is to account for residual correlation at the industry level. This correlation can derive from investors who associate all firms in the same industry (e.g., banking, oil, and telecommunications) with similar behavior after $C U{ }^{10}$

[Table 2 about here]

Consider first the results in Panel A. We find that Connection is negatively associated with the announcement return. The loss of value for firms with connections suggests a reduction in the market value of political connections: a marginal political connection lowers firm value by $\$ 6.9$ million (\$8.3 million) for an average firm, which equals the three-day (five-day) announcement return of $-0.1 \%(-0.12 \%)$ times the sample-average market capitalization of $\$ 6.9$ billion. This evidence is consistent with the crowding-out effect of independent political spending, the newly available form of political activism after $C U$, over political connections.

Consistent with evidence in Werner (2011), the coefficients on other political variables, Lobbying, ${ }^{11}$ Executive contribution, and PAC Contribution are insignificant, suggesting that they are not close substitutes to independent political spending. We discuss in the introduction of the

\footnotetext{
${ }^{10}$ The results are essentially unchanged if standard errors are clustered by state or firm. We also find similar results if we add state dummies in the regressions.

${ }^{11}$ We use lobbying spending in 2009 as an alternative variable for lobbying, and use the sum of contributions made by both current and past executives - provided the contributions are made during the tenure as a top executive of the firm-as an alternative to our measure of executive contributions. The results are similarly insignificant with these alternative measures of political activism.
} 
paper possible justifications for this non-result. These justifications point to other measures of political activism not being directly under the control of management as political connections are, or of having characteristics that make them unique such as lobbying.

In Panel B, we further explore the monotonicity effect of connections by using categorical dummy variables. High Connection is a dummy variable that equals one if firms have 6 or more political connections in 2009 (equal to or above percentile 90) and zero otherwise. Low Connection is a dummy variable that equals one if firms have between one and five political connections in 2009 and zero otherwise. Firms in the control group are firms without a connection. The results show that the effect of connections on the announcement return is monotonic. Only the firms in the top decile of connections appear to be significantly affected relative to the omitted group of no connections. The estimated coefficients associated with the dummy for five connections or fewer are all smaller in magnitude and statistically insignificant. ${ }^{12}$ The loss of value for firms with high connections suggests a reduction in the firm value of $\$ 62.1$ million ( $\$ 74.5$ million) relative to the control group, which equals the three-day (five-day) announcement return of $-0.90 \%(-1.08 \%)$ times the sample-average market capitalization of $\$ 6.9$ billion. We offer two explanations for the finding that our results are concentrated in firms with a high level of connections. First, connections may be more salient to analysts and investors if they are pervasive in the company. Second, firms that have spent considerable resources developing a large number of connections

\footnotetext{
${ }^{12} \mathrm{We}$ also re-estimated the model using 5 connections as a cut-off for the definition of High Connection. Firms with $5+$ connections represent 15 percent of our sample. The results are qualitatively similar to those discussed above. Finally, we re-estimated the model using categorical dummy variables for 1 connection, 2 connections, 3 connection, 4 connections, 5 connections, and 6+ connections. The results are again qualitatively similar to those discussed above: only the dummy with $6+$ connections is significant in all specifications (the coefficient associated with the dummy with 5 connections is significant at the $10 \%$ level when we use the event windows $(-1,+1)$ and $(-1,+2)$ ). Quantitatively, this formulation gives the largest effect.
} 
may have over-invested in this traditional form of political capital, and these firms may have the most to lose under the new regime.

The results in these regressions mimic the simple, average cumulative abnormal returns during the event, without including control variables. In the internet appendix, we show that: (i) connected firms have a positive CAR, though lower than that of non-connected firms, (ii) it is the firms with a high number of connections that have the lowest returns, and (iii) firms with the highest number of connections have a negative return.

Table 3 tests whether the effect we find on connections is a governance effect. We repeat the regression in Panel A of Table 2 where the dependent variable is the CAR measured over the window $(-1,+3)$ but add Excesspay, E-Index, G-Index and CEO Duality respectively in columns (1) through (4) as corporate governance control variables. These corporate governance controls do not appear to subsume the effect of connections and in fact, do not even affect the market response. If anything, the coefficient on Connection becomes larger in absolute value. We also use alternative corporate governance variables, such as a founder-CEO dummy, the percentage of independent directors in the board of directors, the excess pay measured by Cai and Walking (2011), and a co-opted board dummy (that equals one if the firm's percentage of directors appointed by the CEO is among the top quintile of the firm-year observations, and zero otherwise), and find similar results.

[Table 3 about here]

While we cluster the standard errors at the industry level in the announcement-return regressions, the results are robust to using bootstrapped $p$-values. Bootstrapped $p$-values account 
for the concern that the announcement could result in a cross-sectional correlation of returns across stocks and thus bias the OLS standard errors even with the industry clustering (see Sefcik and Thompson, 1986, and Bernard, 1987). We use a procedure similar to that of Lo (2003), Zhang (2007), and Cai and Walking (2011). The process generates 10,000 repetitions where each repetition uses sample firm abnormal returns from 50 randomly-selected non-overlapping 3-day windows from non-event periods. This procedure maintains the cross-sectional correlation of firms' returns in the non-event period so that one can assess whether the event returns are statistically significant after taking into account any cross-sectional dependence generated by the event.

\section{B. Changes in Political Connections after Citizens United}

We next test whether political activism changed after $C U$ using a window from 2007 to 2012. We construct the variable Post Dummy that equals one from 2010 to 2012 and zero from 2007 to 2009. Each of these periods contains two years of a presidential election cycle and one year of a mid-term election cycle. If we regress political activism, say Connection, on Post Dummy in the absence of a control group, we cannot claim that the effect we find is due to the $C U$ decision because unobserved concurrent events could also cause it. To conduct this test, we use the fact that twenty-three states had bans on independent expenditures by corporations on state elections before $C U$ based on Austin vs. Michigan Chamber of Commerce. ${ }^{13}$ These bans are overruled by $C U$. We thus use firms in ban states as the treatment group and firms in no-ban states as the control group (see also Spencer and Wood, 2014), and define Ban State to equal one if the firm is headquartered

\footnotetext{
${ }^{13}$ Our data is collected from the National Conference of State Legislatures. There were 23 states that prohibited or restricted corporate spending on candidate elections at the time of $C U$, which we define as Ban State. Source: http://www.ncsl.org/research/elections-and-campaigns/citizens-united-and-the-states.aspx.
} 
in a state with bans on independent expenditures on state elections and zero otherwise. We expect firms in ban states that rely on more traditional forms of political activism before $C U$ to circumvent the limitation of using treasury money to fund state-level political campaigns, such as by investing in state-level political connections or PAC contributions, to potentially change the way they engage in political activism.

In Table 4, we present the results on changes in firm connections. (We report the effects on the other forms of political activism in Table 5, which is to be discussed in the next sub-section.) The dependent variable is the number of connections in any given firm and year, which we also break down into national, state, and local connections. The independent variables include Ban State and Post Dummy, but also the interaction of interest, Ban State*Post Dummy. We use an OLS regression model and add lagged firm characteristics that affect the establishment of political connections as control variables. We include three-digit SIC industry dummy variables and cluster standard errors by state. ${ }^{14}$

[Table 4 about here]

The variable Ban State*Post Dummy is significantly negatively associated with All connections and with State connections. The coefficient on State connections is -0.099 , indicating that firms have 0.099 fewer state-level political connections after $C U$ if they headquarter in ban states relative to those firms that locate in no-ban states. The estimated coefficient corresponds to

\footnotetext{
${ }^{14}$ We find similar results if we include 47 industry dummy variables based on Fama-French 48 industries and calculate standard errors clustered by firm. Our results are robust also if we use a Poisson regression model.
} 
an economically sizable effect as the average state-level connection in our 2007 to 2012 sample is 0.73 (i.e., a $13.6 \%$ decrease).

The Ban State*Post Dummy interaction has no explanatory power for local-level connections, possibly because there is not enough power in the data to detect an effect on local connections. While $44 \%$ of the firm-year observations in our 2007 to 2012 sample have state connections (with an average connection of 0.73 ), only $9 \%$ of the firm-year observations have local connections (with an average connection of 0.11 ). We also do not find any significant effect of Ban State*Post Dummy on national-level connections. As explained before, this is consistent with what we expected since companies from any state are prohibited from using independent political spending on national elections before $C U$, and there is no cross-sectional variation across states. In summary, the evidence from state connections suggests that political connections lose some of their value after $C U$, consistent with the crowding-out effect.

The difference-in-differences analysis of Table 4 requires that any trends in outcomes for the treatment and control groups before treatment are the same (i.e., the "parallel trends" assumption). The "parallel trends" assumption holds in our setting as the difference in average growth rates of political connections across the treatment and control groups of firms before $C U$ is not statistically significant. Also, we check that firms in ban states do not move to non-ban states during the period of analysis or vice-versa.

It is possible that our results are influenced by the fact that firms do not choose their state of incorporation randomly. We exclude firms headquartered in Delaware and obtain similar results. We also look to see if there is any significant difference in political leaning in ban states versus no-ban states to account for the possibility that Democratic-leaning states promote legal bans on spending. Our data suggest that ban states are more likely to be Republican-leaning than no-ban 
states, but the difference is statistically insignificant. Moreover, ban and no-ban states might differ in their industries, and this difference could condition the response of connections to $C U$. However, we find no difference in industry composition across ban and no-ban states.

We also consider the possibility of confounding bias or omitted correlated variable. Spencer and Wood (2014) argue that the level of political competition can create a confounding bias, which in our exercise implies that increased political competition may lead to higher independent expenditures and political connections. In the online appendix, we tabulate results where the models in Table 4 are extended to also control for a Political Competition Index. ${ }^{15}$ The results are qualitatively the same as those in the paper.

\section{Changes in Lobbying, PAC and Executive Contributions After CU}

In Table 5, we examine changes in lobbying expenditures, executive contributions, and PAC contributions after $C U$. Otherwise, the regression specification mimics that of Table 4. Except for PAC contributions, lobbying and executive contributions are not restricted to state elections. Therefore, we expect no significant change in lobbying and executive contributions in ban versus no-ban states from pre- to post- $C U$ periods. Table 5 shows that indeed, the interaction Ban State Post Dummy is insignificant for lobbying expenditures and executive contributions. Further, we find that Ban State*Post Dummy is insignificantly related to PAC contributions. The result suggests that PAC contributions are not sensitive to the introduction of independent political spending as a new mechanism for political activism.

\footnotetext{
15 The political competition index for state $i$ and year $j$ is $P C_{i j}=-\left|\frac{L H D_{i j}+U H D_{i j}}{L H D_{i j}+U H D_{i j}+L H R_{i j}+U H R_{i j}}-0.5\right|$, where $L H D_{i j}$ $\left(L H R_{i j}\right)$ and $U H D_{i j}\left(U H R_{i j}\right)$ represent the number of seats that Democrats (Republicans) hold, respectively, in the lower and upper chambers of the state legislature that was elected in year $j$. The range of the index is from -0.5 to 0 .
} 
The Post Dummy is significant and positive for PAC contribution, which replicates the finding in Coates (2012) of an increase in PAC contributions after $C U$. One advantage of our differencein-differences exercise over the regression analysis conducted by Coates is that we use the heterogeneity on state bans: we can identify the treated firms as those firms in states that had bans on independent expenditures prior to $C U$ and use firms in states that had no bans on independent expenditures before $C U$ as control firms. This additional source of heterogeneity solves the issue of concurrent events that we are unable to control and can confound the causal inference associated with $C U$.

[Table 5 about here]

\section{Political Connections by Executives, Board Members, and Others}

We provide evidence consistent with a crowding-out effect of independent political spending over political connections. Faccio (2006) shows that political connections by board members are very different from those by executives: while the former does not grant a significant advantage to the firm, the latter does. In this section, we examine the heterogeneity of this crowding-out effect based on the type of political connections.

BoardEx classifies individuals in the firm into three groups: executives, board members, and others. In line with this classification, we define a political connection as Executive Connection if the classification of the individual includes $\mathrm{CEO}, \mathrm{CFO}$, or COO. We define a political connection as Board Connection if the classification of the individual includes independent director, director,

or independent/deputy chairman. Finally, we define a political connection as Other Connection if the job title of the individual includes senior VP, division/regional president, or general manager. 
Panel A of Table 6 presents the results on announcement returns, and Panel B of Table 6 presents the results on changes in the number of connections after $C U$. In the first two columns of Panel A, a connection is defined as Executive Connection, in the next two columns connection is defined as Board Connection, and in the last two columns, we have Other Connection. We present results for both continuous definition of connections and categorical definition of connections and use event window $(-1,+3)$, though the results are qualitatively the same if we use any of the other event windows in Table 2. High Connections is defined by the percentile 90 of connections, which varies across types of connections: it is 2 or more for executive connections, 4 or more for board connections, and 3 or more for other connections.

The results show that it is the Board and Other Connections that lose value, though there is only mild significance for the value effect of Board Connection (see columns (3) through (6)). In contrast, executive connections do not lose value around the announcement of $C U$, which indicates that executive connections maintain their value to the firm and are less substitutable when independent expenditures become available after $C U$. In the last column of Panel $\mathrm{A}$, we find a $1.14 \%$ lower announcement return for firms with a high number of Other Connection relative to those with zero Other Connection, which is economically significant. The result shows that Other Connection might be the least significant form of connections to the firm, and most substitutable when the new avenue of political activism becomes available.

[Table 6 about here]

In Panel $\mathrm{B}$ of Table 6, we further test how each type of connection changes after $C U$. In the first two columns of Panel B, a connection is defined as Executive Connection, in the next two 
columns connection is defined as Board Connection, and in the last two columns, we have Other Connection. For each connection type, the first column is for all connections, and the second column is for state connections. The results in the table indicate that firms in ban states have fewer Other Connection after $C U$ than those in no-ban states. In the last column of Panel B, the coefficient of Ban State*Post Dummy is -0.087 . The result suggests that firms have 0.087 fewer state-level other connections after $C U$ if they headquarter in ban states relative to those firms that locate in no-ban states. The estimated coefficient corresponds to an economically sizable effect as the average state-level other connection in our sample is 0.501 (i.e., a $17.4 \%$ decrease).

Faccio, Masulis, and McConnell (2006) show that if a firm's political connection is established through its top officers (CEO, Chairman, etc.), then such a firm is more likely to be bailed out during tough times than matching firms. In other words, connections via top executives appear to be more effective in their context. Their evidence is consistent with ours that executive connections do not lose value around the announcement of $C U$.

\section{E. Political Sensitivity of Regulated Industries}

In this section, we investigate heterogeneous effects based on whether an industry is regulated (i.e., Transportation, Communication and Utilities, with SIC between 4399 and 5001) or nonregulated (all others). ${ }^{16}$ The results are shown in Table 7 . Regulated industries display a strong positive, and significant market reaction ( $t$-stats are above 7). This is consistent with Burns and Jindra (2014) who find similar evidence. They argue that regulated industries have greater interaction with the government and may benefit more from having more avenues to advance their

\footnotetext{
${ }^{16}$ Results are robust for a different definition of the regulated industry: Regulated Industry Dummy equals one if SIC is between 4000 and 5000 and zero otherwise.
} 
agendas. In addition to this result, we show that firms with high connections in non-regulated industries experience significantly negative announcement returns, whereas connections do not affect announcement returns in regulated industries. It suggests that political connections in nonregulated industries lose value, as they are more substitutable than those in regulated industries. This result is consistent with those in Faccio (2006, 2010), who argues that firms in regulated industries are more likely to harness the benefits from political and government connections. ${ }^{17}$

[Table 7 about here]

\section{Robustness Tests}

We conduct several robustness tests. First, we look for other confounding, contemporaneous information events. The same day that the Supreme Court ruling was announced, President Obama publicly endorsed the Volcker rule that commercial banks should not be allowed to engage in proprietary trading. ${ }^{18}$ Paul Volcker had "campaigned" for the rule during much of 2009, but the decision to adopt it may still have come as a surprise to some because of its controversy. While our tests include industry dummies to ensure the results are not driven by a particular industry, to further minimize this concern, we also drop financial firms (i.e., SIC codes between 6000 and 6999) from our sample. The results remain qualitatively similar after excluding financial firms.

\footnotetext{
${ }^{17}$ For completeness, we have repeated the exercise in Table 7 for lobbying, executive contributions, and PAC contributions. We find that firms in regulated industries whose executives made contributions to candidates experience significantly positive announcement returns whereas executive contributions appear not to affect announcement returns in non-regulated industries.

18 The full text of the speech is available at http://blogs.wsj.com/deals/2010/01/21/full-text-of-obamas-remarks-onfinancial-reform/.
} 
Second, we investigate whether top customers of the company affect the relationship between political activism and firm value. We collect data from Compustat and create the variable Government Dummy that equals one if at least one top customer of the firm is government-related and zero otherwise. As political connections help obtain government procurement contracts (Goldman, Rocholl and So, 2013), we expect a weaker effect if one of the top customers in a firm is government-related. Consistent with this, we find that Government Dummy*Connection is positively associated with the three-day CAR although the coefficient is insignificant. Government Dummy itself is insignificant as well, and our main results still hold.

Third, we add state-level political competition as a control variable using two measures suggested in previous literature: Political Competition Index, described above, and Divided Government Dummy. Divided Government Dummy equals one if the state government is divided (different parties control different branches of government) and zero if the state government is unified. We wish to control for the possibility that the marginal benefit of political connections depends on the state-level political system. For example, after $C U$, political connections become significantly less valuable for firms in states with more political competition between political parties. Consistent with this, we find that Political Competition Index*Connection is negatively associated with the three-day CAR, but the coefficient is insignificant. Other results remain qualitatively the same as before. We also winsorize Connection, Lobbying, Executive Contributions, and PAC Contributions, and the results are similar to those reported above.

Fourth, on June $29^{\text {th }}, 2009$, the Supreme Court decided that a rehearing was needed so the parties could address the question of whether a resolution of the case was tied to, among other things, the overruling of Austin vs. Michigan Chamber of Commerce, which upheld a state law prohibiting an independent political expenditure by the nonprofit Michigan Chamber of 
Commerce. The rehearing happened on September $9^{\text {th }}, 2009$. Expanding the scope of the case and ordering new oral arguments by the Court is rare and may have provided a signal to expert observers that the likely outcome was a ruling in favor of $C U$. We repeat the stock market announcement analysis for each of these dates. We find that Connection is statistically insignificant on either date. While there could be many reasons for these results, it is possible that a significant amount of uncertainty about the final ruling still remained, which was only truly resolved on January 21, 2010.

Our last robustness checks are placebo tests. We use the three-day CAR from -1 to +1 when day 0 is two weeks before/after the date when the $C U$ decision is announced (January 21, 2010). We find that Connection, Lobbying, Executive Contributions, and PAC Contributions are all statistically insignificant with or without corporate governance control variables. We also eliminate the $C U$ effect and examine changes of political connections where the pre-period is 20042006 and the post-period is 2007-2009. The results show that the coefficient associated with the Ban State*Post Dummy is insignificant in all specifications. This evidence supports our identification strategy of using ban states as the treatment group for an analysis of changes in political activism following $C U$.

\section{Conclusion}

The paper studies the political activism of publicly traded corporations using the Supreme Court ruling on Citizens United vs. FEC for identification. $C U$ promotes a radical change in the political activism landscape by allowing corporate treasuries to fund political campaigns directly. As it was mostly unanticipated, $C U$ constitutes an exogenous identification shock to substitutability across different forms of political activism and allows us to address the quest set 
by Issacharoff and Karlan (1999) to understand where and why money in politics flows where it does.

We find that political connections lose value, suggesting a crowding-out effect of independent political spending over political connections. We confirm this finding by analyzing changes in connections at the firm-level using an identification strategy rooted in the fact that, before $C U$, some states had bans on state-level independent political spending. Consistent with the evidence on announcement returns, after the ruling, corporations headquartered in ban states have fewer state-level political connections relative to corporations in no-ban states. We find that the value of lobbying, PAC contributions, and executive contributions was not affected by $C U$, suggesting that these forms of political activism are less substitutable for corporate treasury money.

Our work focuses on the intensive margin of political activism. It is interesting also to ask whether an extensive margin of response can be observed where firms that were politically inactive ex-ante start engaging in political activism because of $C U$. We leave this question for future research. 


\section{References}

Acemoglu, D., Johnson, S., Kermani, A., Kwak, J., and Mitton, T., 2016. "The value of connections in turbulent times: evidence from the United States.", Journal of Financial Economics $121,368-391$.

Akey, P., 2015. "Valuing changes in political networks: Evidence from campaign contributions to close congressional elections." Review of Financial Studies 28, 3188-223.

Amore, M., and Bennedsen, M., 2013. "The value of local political connections in a low-corruption environment", Journal of Financial Economics 110, 387-402.

Ansolabehere, S., Snyder, J., and Tripathi, M., 2002. "Are PAC contributions and lobbying linked? New evidence from the 1995 Lobby Disclosure Act.” Business and Politics 4, 31-155.

Austen-Smith, D., 1995. "Campaign contributions and access.” American Political Science Review $89,566-581$.

Bebchuk, L.A., Cohen, A., and Ferrell, A., 2009. "What matters in corporate governance?" Review of Financial Studies 22, 783-827.

Bebchuk, L.A., and Jackson Jr, R.J., 2012. "Shining light on corporate political spending." Geogetowm Law Journal 101, 923-967.

Bebchuk, L.A., and Jackson Jr, R.J., 2015. "Hindering the SEC from shining a light on political spending." New York Times DealBook, December 2015.

Bernard, V.L., 1987. "Cross-sectional dependence and problems in inference in market-based accounting research.” Journal of Accounting Research 25, 1-48.

Bertrand, M., Bombardini, M., and Trebbi, F., 2014. "Is it whom you know or what you know? an empirical assessment of the lobbying process." American Economic Review 104, 3885-3920. 
Blau, B.M., Tyler B., and Diana W. T., 2013. "Corporate Lobbying, Political Connections, and the Bailout of Banks." Journal of Banking and Finance 37, 3007-3117.

Briffault, R., 2008. "Lobbying and Campaign Finance: Separate and Together" Stanford Law and Policy Review 19, 105-129.

Bunkanwanicha, P., and Wiwattanakantang, Y., 2009. "Big business owners in politics.” Review of Financial Studies 22, 2133-2168.

Burns, N., and Jindra, J., 2014. "Political Spending and Shareholder Wealth: The Effect of the U.S. Supreme Court Ruling in Citizens United." American Politics Research 42, 579-599.

Cai, J. and Walkling, R., 2011. "Shareholders say on pay: does it create value?" Journal of Financial and Quantitative Analysis 46, 299-339.

Cohn, Y., Kelley, K. H., and Kess, A.J., 2016. "Political Contributions and Lobbying Proposals." https://corpgov.law.harvard.edu/2016/08/18/political-contributions-and-lobbying-proposals/

Copland, J.R., and O'Keefe, M.M., 2016. "Political Spending and Lobbying." http://www.proxymonitor.org/Forms/2016Finding3.aspx

Coates, J.C.IV., 2012. “Corporate politics, governance, and value before and after Citizens United." Journal of Empirical Legal Studies 9, 657-696.

Correia, M., 2014. "Political connections and SEC enforcement." Journal of Accounting and Economics 57, 241-262.

Duchin, R., and Sosyura, D., 2012. "The politics of government investment." Journal of Financial Economics 106, 24-48.

Duflo, E., 2001. "Schooling and labor market consequences of school construction in Indonesia: Evidence from an unusual policy experiment." American Economic Review 91, 795-813.

Faccio, M., 2006. “Politically connected firms.” American Economic Review 96, 369-386. 
Faccio, M., 2010. "Differences between Politically Connected and Non-Connected Firms: A Cross-Country Analysis." Financial Management 39, 905-928.

Faccio, M., Masulis, M.W., and McConnell, J.J., 2006. "Political connections and corporate bailouts." Journal of Finance 61, 2597-2635.

Fama, E., and French, K., 1997. "Industry costs of equity." Journal of Financial Economics 43, 153-193.

Fisman, R., 2001. "Estimating the value of political connections." American Economic Review 91, 1095-1102.

Florens, J.P., Heckman, J.J., Meghir, C., and Vytlacil, E., 2008. "Identification of treatment effects using control functions in models with continuous, endogenous treatment and heterogeneous effects.” Econometrica 76, 1191-1206.

Goldman, E., Rocholl, J., and So, J., 2009. "Do politically connected boards affect firm value?" Review of Financial Studies 22, 2331-2360.

Goldman, E., Rocholl, J., and So, J., 2013. "Politically connected boards of directors and the allocation of procurement contracts." Review of Finance 17, 1617-1648.

Gompers, P., Ishii, J., and Metrick, A., 2003. "Corporate governance and equity prices.” Quarterly Journal of Economics, 118, 107-155.

Issacharoff, S., and Karlan, P.S., 1999. "The hydraulics of campaign finance reform.” Texas Law Review 77, 1705-1738.

Johnson, S., and Mitton, T., 2003. "Cronyism and capital controls: evidence from Malaysia." Journal of Financial Economics 67, 351-382.

Khwaja, A., and Mian, A., 2005. "Do lenders favor politically connected firms? Rent provision in an emerging financial market." Quarterly Journal of Economics 120, 1371-1411. 
Kostovetsky, L., 2015. "Political capital and moral hazard.” Journal of Financial Economics 116, 144-159.

Lake, J., 2015. "Revisiting the link between PAC Contributions and Lobbying Expenditures." European Journal of Political Economy 37, 86-101.

Larcker, D.F., Ormazabal, G., and Taylor, D.J., 2011. "The market reaction to corporate governance regulation." Journal of Financial Economics 101, 431-448.

Leuz, C., and Oberholzer-Gee, F., 2006. "Political relationships, global financing, and corporate transparency: evidence from Indonesia." Journal of Financial Economics 81, 411-439.

Lo, K., 2003. "Economic consequences of regulated changes in disclosure: the case of executive compensation." Journal of Accounting and Economics 35, 285-314.

Newton, A.N., and Uysal, V.B., 2013. "The impact of political connectedness on cash holdings: evidence from Citizens United.” University of Oklahoma Working Paper.

Posner, C., 2019. "Is it time for corporate political spending disclosure?" Harvard Law School Forum on Corporate Governance and Financial Regulation, March 2019.

Schoenherr, D., 2019. "Political connections and allocative distortions." Journal of Finance 74, 543-586.

Sefcik, S., and Thompson, R., 1986. "An approach to statistical inference in cross-sectional models with security abnormal returns as dependent variable." Journal of Accounting Research 2, 316334.

Spencer, D., and Wood, A., 2014. "Citizens United, states divided: an empirical analysis of independent political spending." Indiana Law Journal 89, 315-372.

Werner, T., 2011. "The sound, the fury, and the non-event: business power and market reactions to the Citizens United decision." American Politics Research 39, 118-141. 
Westcott, S., 2013. “2013 Proxy Season Preview: Key Shareholder Proposals.” Alliance Advisors Whitepaper: http://blogs.law.harvard.edu/corpgov/2013/03/21/2013-proxy-season-preview-keyshareholder-proposals/

Wright, F., 1996. "Two Lands on One Soil: Ulster Politics before Home Rule.” Dublin: Gill and MacMillian.

Zhang, I.X., 2007. "Economic consequences of the Sarbanes-Oxley Act of 2002." Journal of Accounting and Economics 44, 74-115. 


\section{Table 1. Summary Statistics}

This table presents summary statistics for the variables used in the paper. Connection is the number of political connections firms had with government organizations in 2009. State Connection is the number of state-level political connections firms had with government organizations in 2009. Lobbying is the natural $\log$ of the sum of all prior corporate lobbying expenditures till 2009. Executive Contribution is the natural $\log$ of the total amount of executive contributions. It captures all past contributions made by current executives in 2009 and does not include contributions made by past executives. PAC Contribution is the natural $\log$ of the sum of all prior PAC contributions till 2009. Institutional Ownership is domestic institutional ownership. We follow Gompers, Ishii, and Metrick (2003) and construct G-Index based on 24 governance provisions provided by the Investor Responsibility Research Center (IRRC). E-Index is proposed by Bebchuk, Cohen, and Ferrell (2009) and based on six provisions: staggered boards, limits to shareholder bylaw amendments, poison pills, golden parachutes, and supermajority requirements for charter amendments and mergers. We follow Larcker, Ormazabal, and Taylor (2011) and measure Excesspay as the difference between CEO compensation and the median compensation of a set of peer firms in the same industry and of similar size as that of the firm. CEO Duality is a binary variable that equals one if the CEO held the position of chairman of the board as of December 31, 2009 and zero otherwise. CAR is the threeday abnormal return from -1 to +1 where day 0 is January 21, 2010 when Citizens United ruling is announced. Size is the natural log of the market value of equity (item $25 *$ item 24 ). BM is the book value of equity (item 60) divided by market value of equity (item $25 *$ item 24). Past Return is the past stock return for the previous twelve months. ROA is operating income (item 13) divided by book assets (item 6). Debt is the Book value of debt (item 9+ item 34) divided by book assets (item 6). Cash is Cash holdings (item 1) over book assets (item 6). Sales Growth is the difference between current sales (item 12) and lagged sales, all divided by lagged sales.

\begin{tabular}{ccccccc}
\hline Variables & $\mathbf{N}$ & Mean & $\mathbf{1 0}^{\text {th }}$ Perc. & Median & $\mathbf{9 0}^{\text {th }}$ Perc. & Std. Dev \\
\hline Connection & 1,722 & 2.27 & 0.00 & 1.00 & 6.00 & 3.06 \\
State Connection & 1,722 & 0.76 & 0.00 & 0.00 & 2.00 & 1.21 \\
Lobbying & 1,722 & 5.85 & 0.00 & 0.00 & 15.95 & 7.16 \\
Executive Contribution & 1,722 & 8.63 & 0.00 & 9.66 & 12.01 & 3.60 \\
PAC Contribution & 1,722 & 3.04 & 0.00 & 0.00 & 11.54 & 4.95 \\
Institutional Ownership & 1,722 & 0.67 & 0.12 & 0.75 & 0.94 & 0.28 \\
G-Index & 1,429 & 7.42 & 6.00 & 7.00 & 9.00 & 1.51 \\
E-Index & 1,429 & 3.68 & 2.00 & 4.00 & 5.00 & 1.14 \\
Excesspay & 1,722 & -0.07 & -0.98 & 0.00 & 0.79 & 0.87 \\
CEO Duality & 1,636 & 0.51 & 0.00 & 1.00 & 1.00 & 0.50 \\
CAR & 1,722 & 0.01 & -0.03 & 0.00 & 0.06 & 0.05 \\
Size & 1,722 & 7.41 & 5.53 & 7.32 & 9.51 & 1.60 \\
BM & 1,722 & 0.64 & 0.18 & 0.55 & 1.18 & 0.53 \\
Past Return & 1,722 & 0.04 & -0.00 & 0.03 & 0.10 & 0.05 \\
ROA & 1,722 & 0.02 & -0.09 & 0.03 & 0.11 & 0.11 \\
Debt & 1,722 & 0.22 & 0.00 & 0.19 & 0.48 & 0.19 \\
Cash & 1,722 & 0.16 & 0.01 & 0.10 & 0.40 & 0.16 \\
Sales Growth & 1,722 & -0.06 & -0.30 & -0.05 & 0.15 & 0.19 \\
\hline
\end{tabular}




\section{Table 2. Political Activism and Firm Value}

This table shows the results from regressing announcement returns on measures of political activism. The dependent variable is the percentage CAR measured over different event windows where day 0 is January 21, 2010 when $C U$ is announced. In Panel A, Connection is the number of political connections firms had with government organizations in 2009. Lobbying is the natural log of the sum of all prior corporate lobbying expenditures before the end of 2009. Executive Contribution is the natural log of the total amount of executive contribution. It captures all past contributions made by current executives in 2009. PAC Contribution is the natural $\log$ of the sum of all prior PAC contributions before the end of 2009. In Panel B, High Connection is a dummy variable that equals one if firms have 6 or more political connections in 2009 and zero otherwise. Low Connection is a dummy variable that equals one if firms have 5 or less (but non-zero) political connections in 2009 and zero otherwise. The complete definitions of the control variables can be found in the appendix. We winsorize each control variable at percentiles 1 and 99. We include industry dummies based on three-digit SIC code and cluster standard errors by industry. $* * *, * *$, and $*$ represent the $1 \%, 5 \%$, and $10 \%$ significance level, respectively.

Panel A.

\begin{tabular}{|c|c|c|c|c|}
\hline & \multicolumn{4}{|c|}{ Announcement Returns } \\
\hline & $(-1,+1)$ & $(0,+1)$ & $(-1,+2)$ & $(-1,+3)$ \\
\hline \multirow[t]{2}{*}{ Connection } & -0.104 & -0.094 & -0.107 & -0.123 \\
\hline & {$[2.83]^{* * *}$} & {$[2.13]^{* *}$} & {$[2.33]^{* * *}$} & {$[2.45]^{* * *}$} \\
\hline \multirow[t]{2}{*}{ Lobbying } & 0.019 & 0.004 & 0.019 & 0.026 \\
\hline & [0.99] & {$[0.30]$} & {$[0.97]$} & [1.31] \\
\hline Executive & 0.041 & 0.042 & 0.031 & 0.050 \\
\hline Contribution & [0.99] & {$[1.07]$} & {$[0.68]$} & {$[1.13]$} \\
\hline \multirow[t]{2}{*}{ PAC Contribution } & -0.027 & -0.022 & -0.022 & -0.021 \\
\hline & {$[1.21]$} & [1.14] & {$[1.00]$} & {$[0.76]$} \\
\hline Institutional & 0.525 & 0.849 & 0.744 & 0.860 \\
\hline Ownership & [1.11] & {$[1.91]^{*}$} & {$[1.54]$} & {$[1.58]$} \\
\hline \multirow[t]{2}{*}{ Size } & -0.040 & -0.118 & 0.067 & 0.171 \\
\hline & {$[0.35]$} & [1.36] & {$[0.60]$} & [1.13] \\
\hline \multirow[t]{2}{*}{$B M$} & 0.962 & 0.344 & 0.892 & 0.804 \\
\hline & {$[1.53]$} & {$[0.83]$} & {$[1.25]$} & {$[0.93]$} \\
\hline \multirow{2}{*}{ Past Return } & -5.596 & -2.105 & -8.828 & -8.812 \\
\hline & {$[1.27]$} & {$[0.67]$} & {$[1.65]$} & {$[1.35]$} \\
\hline \multirow[t]{2}{*}{$R O A$} & 0.490 & 0.651 & 0.378 & -0.995 \\
\hline & {$[0.33]$} & [0.47] & {$[0.26]$} & {$[0.53]$} \\
\hline \multirow[t]{2}{*}{ Debt } & 1.422 & 0.323 & 2.308 & 2.626 \\
\hline & {$[1.68]^{*}$} & {$[0.37]$} & {$[2.42]^{* * *}$} & {$[2.37]^{* * *}$} \\
\hline \multirow[t]{2}{*}{ Cash } & 1.294 & 0.111 & 1.414 & 1.516 \\
\hline & [1.19] & {$[0.15]$} & [1.23] & [1.34] \\
\hline \multirow[t]{2}{*}{ Sales Growth } & -1.671 & -1.311 & -1.758 & -0.951 \\
\hline & {$[2.39]^{* * *}$} & {$[2.07]^{* *}$} & {$[2.35]^{* * *}$} & [1.05] \\
\hline Industry FE & Yes & Yes & Yes & Yes \\
\hline Adjusted $R^{2}$ & 0.27 & 0.19 & 0.22 & 0.18 \\
\hline$N$ & 1,722 & 1,722 & 1,722 & 1,722 \\
\hline
\end{tabular}


Panel B.

\begin{tabular}{|c|c|c|c|c|}
\hline & \multicolumn{4}{|c|}{ Announcement Returns } \\
\hline & $(-1,+1)$ & $(0,+1)$ & $(-1,+2)$ & $(-1,+3)$ \\
\hline \multirow[t]{2}{*}{ Low Connection } & -0.084 & -0.130 & -0.293 & 0.146 \\
\hline & {$[0.38]$} & {$[0.55]$} & {$[1.21]$} & {$[0.56]$} \\
\hline \multirow[t]{2}{*}{ High Connection } & -0.895 & -0.848 & -1.127 & -1.078 \\
\hline & {$[3.03] * * *$} & {$[2.85]^{* * *}$} & {$[2.88]^{* * *}$} & {$[2.45]^{* * *}$} \\
\hline \multirow[t]{2}{*}{ Lobbying } & 0.016 & 0.002 & 0.020 & 0.022 \\
\hline & {$[0.88]$} & {$[0.16]$} & [1.09] & [1.16] \\
\hline \multirow{2}{*}{$\begin{array}{c}\text { Executive } \\
\text { Contribution }\end{array}$} & 0.038 & 0.040 & 0.004 & 0.045 \\
\hline & {$[0.92]$} & {$[1.04]$} & {$[0.09]$} & {$[1.01]$} \\
\hline \multirow[t]{2}{*}{ PAC Contribution } & -0.030 & -0.024 & -0.019 & -0.026 \\
\hline & {$[1.35]$} & {$[1.27]$} & {$[0.72]$} & [0.94] \\
\hline \multirow{2}{*}{$\begin{array}{l}\text { Institutional } \\
\text { Ownership }\end{array}$} & 0.487 & 0.827 & 1.155 & 0.757 \\
\hline & [1.06] & {$[1.90]^{*}$} & {$[2.12]^{* *}$} & [1.42] \\
\hline \multirow[t]{2}{*}{ Size } & -0.060 & -0.135 & 0.053 & 0.156 \\
\hline & {$[0.47]$} & {$[1.62]$} & {$[0.35]$} & [0.96] \\
\hline \multirow[t]{2}{*}{$B M$} & 0.926 & 0.311 & 1.029 & 0.775 \\
\hline & {$[1.51]$} & {$[0.78]$} & [1.39] & {$[0.91]$} \\
\hline \multirow[t]{2}{*}{ Past Return } & -5.647 & -2.143 & -11.775 & -8.913 \\
\hline & [1.29] & {$[0.68]$} & {$[2.05]^{* *}$} & [1.37] \\
\hline \multirow[t]{2}{*}{$R O A$} & 0.551 & 0.701 & 0.459 & -0.914 \\
\hline & [0.37] & {$[0.51]$} & {$[0.27]$} & [0.49] \\
\hline \multirow[t]{2}{*}{ Debt } & 1.396 & 0.293 & 2.689 & 2.635 \\
\hline & {$[1.66]^{*}$} & {$[0.34]$} & {$[2.50]^{* * *}$} & {$[2.37] * * *$} \\
\hline \multirow[t]{2}{*}{ Cash } & 1.268 & 0.085 & 1.920 & 1.490 \\
\hline & [1.16] & {$[0.11]$} & [1.63] & [1.31] \\
\hline \multirow[t]{2}{*}{ Sales Growth } & -1.681 & -1.327 & -1.802 & -0.963 \\
\hline & {$[2.40] * * *$} & {$[2.08] * *$} & {$[1.83]^{*}$} & [1.06] \\
\hline Industry FE & Yes & Yes & Yes & Yes \\
\hline Adjusted $R^{2}$ & 0.26 & 0.19 & 0.17 & 0.18 \\
\hline$N$ & 1,722 & 1,722 & 1,722 & 1,722 \\
\hline
\end{tabular}




\section{Table 3. Political Activism and Firm Value with Corporate Governance Controls}

This table shows the results from regressing announcement returns on measures of political activism, controlling for corporate governance variables. The dependent variable is the percentage CAR measured over the window $(-1,+3)$, where day 0 is January 21, 2010 when $C U$ is announced. Political activism variables are as in Table 2 . We follow Larcker, Ormazabal, and Taylor (2011) and measure Excesspay as the difference between CEO compensation and the median compensation of a set of peer firms in the same industry and of similar size as that of the firm. E-Index is proposed by Bebchuk, Cohen, and Ferrell (2009) and based on six provisions: staggered boards, limits to shareholder bylaw amendments, poison pills, golden parachutes, and supermajority requirements for charter amendments and mergers. We follow Gompers, Ishii, and Metrick (2003) and construct G-Index based on 24 governance provisions provided by the Investor Responsibility Research Center (IRRC). CEO Duality is a binary variable that equals one if the CEO held the position of chairman of the board as of December 31, 2009 and zero otherwise. The complete definitions of the control variables can be found in the appendix. We winsorize each control variable at percentiles 1 and 99 . We include industry dummies based on three-digit SIC code and cluster standard errors by industry. ***, **, and * represent the $1 \%, 5 \%$, and $10 \%$ significance level, respectively.

\begin{tabular}{|c|c|c|c|c|}
\hline & \multicolumn{4}{|c|}{ Announcement Returns over $(-1,+3)$} \\
\hline & (1) & (2) & (3) & (4) \\
\hline \multirow{2}{*}{ Connection } & -0.124 & -0.150 & -0.147 & -0.132 \\
\hline & {$[2.43]^{* * *}$} & {$[3.23]^{* * *}$} & {$[3.25]^{* * *}$} & {$[2.54]^{* * *}$} \\
\hline \multirow[t]{2}{*}{ Lobbying } & 0.025 & 0.014 & 0.014 & 0.019 \\
\hline & [1.30] & [0.67] & {$[0.67]$} & [0.96] \\
\hline Executive & 0.050 & 0.051 & 0.050 & 0.065 \\
\hline Contribution & [1.14] & {$[0.88]$} & {$[0.87]$} & {$[1.36]$} \\
\hline \multirow[t]{2}{*}{ PAC Contribution } & -0.021 & -0.042 & -0.042 & -0.019 \\
\hline & {$[0.75]$} & [1.53] & [1.53] & {$[0.67]$} \\
\hline Excesspay & $\begin{array}{l}-0.039 \\
{[0.26]}\end{array}$ & & & \\
\hline E-Index & & $\begin{array}{l}0.174 \\
{[1.01]}\end{array}$ & & \\
\hline G-Index & & & $\begin{array}{c}0.140 \\
{[0.96]}\end{array}$ & \\
\hline CEO Duality & & & & $\begin{array}{l}-0.027 \\
{[0.07]}\end{array}$ \\
\hline Institutional & 0.874 & 0.693 & 0.700 & -0.096 \\
\hline Ownership & [1.62] & [1.21] & [1.21] & [0.15] \\
\hline \multirow[t]{2}{*}{ Size } & 0.173 & 0.347 & 0.351 & 0.120 \\
\hline & [1.15] & {$[3.15] * * *$} & {$[3.20]^{* * *}$} & {$[0.75]$} \\
\hline \multirow[t]{2}{*}{$B M$} & 0.808 & 1.837 & 1.829 & 0.682 \\
\hline & [0.93] & [1.56] & [1.57] & {$[0.74]$} \\
\hline \multirow{2}{*}{ Past Return } & -8.747 & -15.963 & -15.811 & -9.400 \\
\hline & [1.33] & {$[2.73]^{* * *}$} & {$[2.75]^{* * *}$} & {$[1.55]$} \\
\hline \multirow[t]{2}{*}{$R O A$} & -1.001 & -0.502 & -0.530 & -2.359 \\
\hline & {$[0.53]$} & {$[0.36]$} & {$[0.38]$} & {$[1.30]$} \\
\hline \multirow[t]{2}{*}{ Debt } & 2.652 & 0.854 & 0.896 & 2.582 \\
\hline & {$[2.36]^{* * *}$} & [1.07] & [1.12] & {$[2.16]^{* *}$} \\
\hline \multirow[t]{2}{*}{ Cash } & 1.509 & -0.656 & -0.586 & 1.343 \\
\hline & [1.34] & {$[0.47]$} & {$[0.42]$} & [1.14] \\
\hline \multirow{2}{*}{ Sales Growth } & -0.933 & 0.150 & 0.192 & -0.969 \\
\hline & [1.04] & {$[0.16]$} & {$[0.21]$} & [1.08] \\
\hline Industry FE & Yes & Yes & Yes & Yes \\
\hline Adjusted $R^{2}$ & 0.18 & 0.18 & 0.18 & 0.16 \\
\hline$N$ & 1,722 & 1,429 & 1,429 & 1,636 \\
\hline
\end{tabular}


Table 4. Changes of Political Connections after $C U$

This table shows how political connections changed with $C U$ using OLS regressions. The dependent variable in column (1) is the number of political connections firms had with all government organizations. From columns (2) to (4), the dependent variable is the number of connections established with the government of national-, state- and local-level, respectively. Ban State is a binary variable that equals one if the firm is headquartered in a state that had bans on independent expenditures on state elections and zero otherwise. Post Dummy is a dummy variable that equals one from 2010 to 2012 and zero from 2007 to 2009. Lobbying is the natural log of the amount of corporate lobbying expenditures. Executive Contribution is the natural log of the amount of executive contributions. PAC Contribution is the natural log of the amount of PAC contributions. The complete definitions of the control variables can be found in the appendix. We winsorize each control variable at percentiles 1 and 99. We include time and three-digit SIC industry dummy variables. Standard errors are clustered by state. $* * *, * *$, and $*$ represent the $1 \%, 5 \%$, and $10 \%$ significance level, respectively.

\begin{tabular}{|c|c|c|c|c|}
\hline & All & National & State & Local \\
\hline \multirow[t]{2}{*}{ Ban State } & -0.273 & -0.204 & -0.115 & 0.045 \\
\hline & {$[2.17] * *$} & {$[2.03] * *$} & {$[1.78]^{*}$} & {$[2.08]^{* *}$} \\
\hline \multirow[t]{2}{*}{ Post Dummy } & 0.534 & 0.190 & 0.281 & 0.063 \\
\hline & {$[6.08]^{* * *}$} & {$[3.10]^{* * *}$} & {$[7.64]^{* * *}$} & {$[4.55]^{* * *}$} \\
\hline Ban State*Post & -0.178 & -0.070 & -0.099 & -0.009 \\
\hline Dummy & {$[2.12]^{* *}$} & {$[1.22]$} & {$[3.14]^{* * *}$} & {$[0.67]$} \\
\hline \multirow[t]{2}{*}{ Lobbying } & 0.000 & 0.000 & 0.000 & 0.000 \\
\hline & [0.97] & [0.92] & [1.08] & [0.92] \\
\hline Executive & 0.000 & 0.000 & 0.000 & 0.000 \\
\hline Contribution & {$[2.18] * *$} & {$[2.26] * *$} & {$[1.76]^{*}$} & {$[1.02]$} \\
\hline \multirow[t]{2}{*}{ PAC Contribution } & 0.000 & 0.000 & 0.000 & 0.000 \\
\hline & {$[1.32]$} & [0.99] & {$[1.70]^{*}$} & {$[1.95]^{*}$} \\
\hline Institutional & -0.951 & -0.611 & -0.258 & -0.082 \\
\hline Ownership & {$[3.18] * * *$} & {$[3.28]^{* * *}$} & {$[1.85]^{*}$} & {$[2.47] * * *$} \\
\hline \multirow[t]{2}{*}{ Investment } & 0.637 & -0.022 & 0.656 & 0.003 \\
\hline & {$[0.37]$} & {$[0.02]$} & {$[0.86]$} & {$[0.02]$} \\
\hline \multirow[t]{2}{*}{ Leverage } & 0.802 & 0.505 & 0.311 & -0.014 \\
\hline & {$[1.97]^{* *}$} & {$[1.85]^{*}$} & [1.62] & {$[0.28]$} \\
\hline \multirow[t]{2}{*}{ Size } & 1.085 & 0.780 & 0.260 & 0.045 \\
\hline & {$[9.35]^{* * *}$} & {$[8.75]^{* * *}$} & {$[6.38]^{* * *}$} & {$[6.04]^{* * *}$} \\
\hline \multirow[t]{2}{*}{$R O A$} & -2.207 & -1.721 & -0.424 & -0.062 \\
\hline & {$[2.77] * * *$} & {$[2.87]^{* * *}$} & {$[1.70]^{*}$} & {$[0.66]$} \\
\hline \multirow[t]{2}{*}{$B M$} & 1.025 & 0.685 & 0.286 & 0.054 \\
\hline & {$[4.36]^{* * *}$} & {$[4.33]^{* * *}$} & {$[3.20]^{* * *}$} & {$[2.60]^{* * *}$} \\
\hline \multirow[t]{2}{*}{ Cash } & -0.152 & -0.054 & -0.011 & -0.087 \\
\hline & {$[0.31]$} & {$[0.15]$} & {$[0.06]$} & [1.41] \\
\hline \multirow[t]{2}{*}{ Sales Growth } & -0.702 & -0.499 & -0.174 & -0.029 \\
\hline & {$[4.64] * * *$} & {$[4.24]^{* * *}$} & {$[3.96]^{* * *}$} & {$[1.65]^{*}$} \\
\hline Time FE & Yes & Yes & Yes & Yes \\
\hline Industry FE & Yes & Yes & Yes & Yes \\
\hline$R^{2}$ & 0.50 & 0.46 & 0.34 & 0.20 \\
\hline$N$ & 8,762 & 8,762 & 8,762 & 8,762 \\
\hline
\end{tabular}




\section{Table 5. Changes of Lobbying, Executive Contribution, and PAC Contribution after $\boldsymbol{C U}$}

This table shows how lobbying, executive contributions, and PAC contributions changed with $C U$ using OLS regressions. The dependent variable in column (1) is the natural log of corporate lobbying expenditures. The dependent variable in column (2) is the natural log of political contributions made by current executives. The dependent variable in column (3) is the natural log of PAC contributions. Ban State is a binary variable that equals one if the headquarter of the firm locates in the state that had bans on independent expenditures on state elections and zero otherwise. Post Dummy is a dummy variable that equals one from 2010 to 2012 and zero from 2007 to 2009 . Connection is the number of political connections firms had with government organizations. Lobbying is the natural log of the amount of corporate lobbying expenditures. Executive Contribution is the natural $\log$ of the amount of executive contributions. PAC Contribution is the natural log of the amount of PAC contributions. The complete definitions of the control variables can be found in the appendix. We winsorize each control variable at percentiles 1 and 99. We include time and three-digit SIC industry dummy variables. Standard errors are clustered by state. $* * * * *$, and $*$ represent the $1 \%, 5 \%$, and $10 \%$ significance level, respectively.

\begin{tabular}{|c|c|c|c|}
\hline & Lobbying & Executive Contribution & PAC Contribution \\
\hline \multirow[t]{2}{*}{ Ban State } & 0.415 & 0.023 & -0.321 \\
\hline & {$[1.66]^{*}$} & [0.19] & [1.49] \\
\hline \multirow[t]{2}{*}{ Post Dummy } & 0.459 & -1.251 & 0.191 \\
\hline & {$[2.59]^{* * *}$} & {$[7.48]^{* * *}$} & {$[1.65]^{*}$} \\
\hline \multirow[t]{2}{*}{ Ban State*Post Dummy } & 0.158 & -0.117 & 0.122 \\
\hline & {$[0.88]$} & {$[0.63]$} & {$[1.17]$} \\
\hline \multirow[t]{2}{*}{ Connection } & 0.156 & 0.071 & 0.192 \\
\hline & {$[3.02]^{* * *}$} & {$[3.73]^{* * *}$} & {$[3.94]^{* * *}$} \\
\hline \multirow[t]{2}{*}{ Lobbying } & & 0.057 & 0.106 \\
\hline & & {$[4.23]^{* * *}$} & {$[8.53]^{* * *}$} \\
\hline \multirow[t]{2}{*}{ Executive Contribution } & 0.135 & & 0.064 \\
\hline & {$[5.43]^{* * *}$} & & {$[5.18]^{* * *}$} \\
\hline \multirow[t]{2}{*}{ PAC Contribution } & 0.308 & 0.067 & \\
\hline & {$[9.86]^{* * *}$} & {$[4.30]^{* * *}$} & \\
\hline \multirow[t]{2}{*}{ Institutional Ownership } & -0.614 & -0.773 & -0.826 \\
\hline & {$[1.34]$} & {$[2.23]^{* *}$} & {$[3.01]^{* * *}$} \\
\hline \multirow[t]{2}{*}{ Leverage } & 2.503 & 1.553 & -0.107 \\
\hline & {$[4.23]^{* * *}$} & {$[3.89]^{* * *}$} & {$[0.25]$} \\
\hline \multirow[t]{2}{*}{ Size } & 1.310 & 0.552 & 0.477 \\
\hline & {$[12.82]^{* * *}$} & {$[7.78]^{* * *}$} & {$[6.64]^{* * *}$} \\
\hline \multirow[t]{2}{*}{ Cash } & 2.138 & -0.878 & -1.254 \\
\hline & {$[3.44]^{* * *}$} & {$[1.74]^{*}$} & {$[3.52]^{* * *}$} \\
\hline \multirow[t]{2}{*}{$R O A$} & 1.438 & 0.683 & 0.292 \\
\hline & [1.07] & {$[0.64]$} & {$[0.38]$} \\
\hline \multirow[t]{2}{*}{ Tobin's $Q$} & -0.319 & -0.045 & -0.197 \\
\hline & {$[3.02]^{* * *}$} & {$[0.54]$} & {$[3.24] * * *$} \\
\hline \multirow[t]{2}{*}{ Sales Growth } & -0.388 & -0.168 & -0.386 \\
\hline & {$[1.48]$} & {$[0.84]$} & {$[3.04]^{* * *}$} \\
\hline Time FE & Yes & Yes & Yes \\
\hline Industry FE & Yes & Yes & Yes \\
\hline Adjusted $R^{2}$ & 0.43 & 0.32 & 0.45 \\
\hline$N$ & 8,779 & 8,779 & 8,779 \\
\hline
\end{tabular}




\section{Table 6. Different Categories of Political Connections}

Panel A presents results on announcement returns, and Panel B presents results on changes in the number of connections after $C U$. In columns (1) and (2) of Panel A, connections are defined as Executive Connection where the connected individual is a top executive, e.g., a CEO, CFO, or COO. In columns (3) and (4) of Panel A, connection are defined as Board Connection where the connected individual is a board member, e.g., an independent director, director, or independent/deputy chairman. In columns (5) and (6) of Panel A, connections are defined as Other Connection where the connected individual is a senior VP, division/regional president, general manager, etc. High Connection is defined by the percentile 90, which varies across types of connections: it is 2 or more for executive connections, 4 or more for board connections, and 3 or more for other connections. In Panel A, the dependent variable is expressed as the percentage CAR measured over the event window $(-1,+3)$ where day 0 is January 21, 2010 when $C U$ is announced. In column 1 (2) of Panel B, the dependent variable is the number of all (state-level) executive connections from 2007 to 2012. In column 3 (4) of Panel B, the dependent variable is the number of all (state-level) board connections and in column 5 (6) of Panel B, the dependent variable is the number of all (state-level) other connections. The complete definitions of the control variables can be found in the appendix. Standard errors are clustered by industry (state) in Panel A (B). ***, **, and * represent the $1 \%, 5 \%$, and $10 \%$ significance level, respectively.

Panel A. Announcement Returns

\begin{tabular}{|c|c|c|c|c|c|c|}
\hline & \multicolumn{6}{|c|}{ Announcement Returns over $(-1,+3)$} \\
\hline & (1) & (2) & (3) & (4) & (5) & (6) \\
\hline \multirow[t]{2}{*}{ Connection } & -0.066 & & -0.134 & & -0.158 & \\
\hline & {$[0.24]$} & & {$[1.82]^{*}$} & & {$[2.69]^{* * *}$} & \\
\hline Low & & 0.163 & & 0.303 & & 0.542 \\
\hline Connection & & {$[0.49]$} & & {$[0.78]$} & & [1.07] \\
\hline High & & -1.140 & & -0.670 & & -1.142 \\
\hline Connection & & {$[1.17]$} & & {$[1.77]^{*}$} & & {$[2.83]^{* * *}$} \\
\hline \multirow[t]{2}{*}{ Lobbying } & 0.021 & 0.022 & 0.023 & 0.021 & 0.024 & 0.023 \\
\hline & {$[1.12]$} & {$[1.14]$} & [1.19] & {$[1.11]$} & {$[1.21]$} & {$[1.20]$} \\
\hline Executive & 0.044 & 0.045 & 0.047 & 0.044 & 0.046 & 0.047 \\
\hline Contribution & {$[1.00]$} & {$[1.03]$} & {$[1.08]$} & {$[1.00]$} & [1.04] & [1.07] \\
\hline$P A C$ & -0.030 & -0.032 & -0.026 & -0.028 & -0.022 & -0.027 \\
\hline Contribution & [1.10] & [1.17] & [0.96] & [1.07] & {$[0.83]$} & [1.07] \\
\hline \multirow[t]{2}{*}{$I O$} & 0.827 & 0.824 & 0.858 & 0.799 & 0.808 & 0.793 \\
\hline & [1.51] & [1.51] & {$[1.58]$} & [1.47] & [1.49] & [1.47] \\
\hline \multirow[t]{2}{*}{ Size } & 0.074 & 0.073 & 0.118 & 0.108 & 0.165 & 0.147 \\
\hline & {$[0.45]$} & {$[0.44]$} & {$[0.74]$} & {$[0.65]$} & [1.07] & [0.77] \\
\hline \multirow{2}{*}{$B M$} & 0.721 & 0.728 & 0.748 & 0.746 & 0.808 & 0.748 \\
\hline & {$[0.85]$} & {$[0.86]$} & {$[0.88]$} & {$[0.88]$} & {$[0.92]$} & [0.89] \\
\hline \multirow[t]{2}{*}{ Past Return } & -8.870 & -8.758 & -9.048 & -8.888 & -8.592 & -8.862 \\
\hline & [1.34] & [1.32] & [1.36] & [1.36] & [1.33] & [1.35] \\
\hline \multirow[t]{2}{*}{$R O A$} & -0.826 & -0.830 & -0.919 & -0.845 & -0.978 & -0.935 \\
\hline & {$[0.43]$} & {$[0.44]$} & {$[0.49]$} & {$[0.45]$} & {$[0.52]$} & {$[0.49]$} \\
\hline \multirow[t]{2}{*}{ Debt } & 2.558 & 2.496 & 2.572 & 2.528 & 2.638 & 2.543 \\
\hline & {$[2.28]^{* *}$} & {$[2.22]^{* *}$} & {$[2.30]^{* *}$} & {$[2.25]^{* *}$} & {$[2.38]^{* * *}$} & {$[2.31] * *$} \\
\hline \multirow[t]{2}{*}{ Cash } & 1.509 & 1.473 & 1.430 & 1.472 & 1.609 & 1.467 \\
\hline & [1.33] & [1.30] & [1.27] & [1.31] & [1.40] & [1.32] \\
\hline Sales & -0.827 & -0.879 & -0.883 & -0.903 & -0.881 & -0.966 \\
\hline Growth & {$[0.89]$} & {$[0.96]$} & {$[0.96]$} & {$[0.98]$} & {$[0.97]$} & {$[1.06]$} \\
\hline Industry FE & Yes & Yes & Yes & Yes & Yes & Yes \\
\hline Adjusted $R^{2}$ & 0.17 & 0.17 & 0.17 & 0.18 & 0.18 & 0.18 \\
\hline$N$ & 1,722 & 1,722 & 1,722 & 1,722 & 1,722 & 1,722 \\
\hline
\end{tabular}


Panel B. Changes in the Number of Connections after $C U$

\begin{tabular}{|c|c|c|c|c|c|c|}
\hline & (1) & $(2)$ & (3) & (4) & (5) & (6) \\
\hline \multirow[t]{2}{*}{ Ban State } & -0.055 & -0.021 & -0.022 & -0.031 & -0.212 & -0.134 \\
\hline & {$[2.66]^{* * *}$} & {$[1.32]$} & {$[0.28]$} & {$[0.66]$} & {$[2.14]^{* *}$} & {$[2.39] * * *$} \\
\hline \multirow[t]{2}{*}{ Post Dummy } & -0.001 & 0.006 & 0.017 & 0.029 & 0.234 & 0.142 \\
\hline & {$[0.04]$} & {$[0.62]$} & {$[0.44]$} & {$[1.36]$} & {$[3.48]^{* * *}$} & {$[3.32] * * *$} \\
\hline \multirow{2}{*}{$\begin{array}{c}\text { Ban State*Post } \\
\text { Dummy }\end{array}$} & 0.019 & 0.002 & -0.047 & -0.033 & -0.132 & -0.087 \\
\hline & {$[1.70]^{*}$} & {$[0.34]$} & {$[1.28]$} & {$[1.32]$} & {$[2.28] * *$} & {$[2.68] * * *$} \\
\hline \multirow[t]{2}{*}{ Lobbying } & -0.002 & -0.001 & 0.011 & -0.001 & 0.029 & 0.016 \\
\hline & {$[0.96]$} & {$[0.71]$} & {$[2.13]^{* *}$} & {$[0.27]$} & {$[3.88]^{* * *}$} & {$[3.55]^{* * *}$} \\
\hline \multirow{2}{*}{$\begin{array}{c}\text { Executive } \\
\text { Contribution }\end{array}$} & 0.009 & 0.001 & 0.017 & 0.011 & 0.005 & -0.002 \\
\hline & {$[5.84]^{* * *}$} & [1.43] & {$[2.78]^{* * *}$} & {$[2.56]^{* * *}$} & [0.93] & [0.69] \\
\hline \multirow{2}{*}{ PAC Contribution } & 0.008 & 0.004 & 0.048 & 0.021 & 0.088 & 0.043 \\
\hline & {$[2.11]^{* *}$} & {$[3.43]^{* * *}$} & {$[4.11]^{* * *}$} & {$[3.09]^{* * *}$} & {$[3.91]^{* * *}$} & {$[3.49] * * *$} \\
\hline \multirow{2}{*}{$\begin{array}{l}\text { Institutional } \\
\text { Ownership }\end{array}$} & -0.108 & 0.006 & -0.354 & 0.012 & -0.518 & -0.276 \\
\hline & {$[2.49]^{* * *}$} & {$[0.24]$} & {$[3.10]^{* * *}$} & {$[0.13]$} & {$[2.32]^{* *}$} & {$[2.10]^{* *}$} \\
\hline \multirow[t]{2}{*}{ Investment } & -0.307 & 0.042 & -0.096 & -0.500 & 1.776 & 1.109 \\
\hline & [1.38] & {$[0.31]$} & [0.09] & {$[0.84]$} & {$[2.11]^{* *}$} & {$[1.82]^{*}$} \\
\hline \multirow[t]{2}{*}{ Leverage } & 0.071 & 0.049 & -0.039 & -0.191 & 0.580 & 0.500 \\
\hline & [1.16] & [1.57] & [0.17] & [1.34] & {$[1.58]$} & {$[2.05]^{* *}$} \\
\hline \multirow[t]{2}{*}{ Size } & 0.047 & -0.000 & 0.394 & 0.123 & 0.610 & 0.267 \\
\hline & {$[6.55]^{* * *}$} & [0.09] & {$[9.39]^{* * *}$} & {$[5.14]^{* * *}$} & {$[5.43]^{* * *}$} & {$[4.22] * * *$} \\
\hline \multirow[t]{2}{*}{$R O A$} & -0.019 & 0.009 & -1.121 & -0.171 & -1.549 & -0.652 \\
\hline & {$[0.24]$} & {$[0.15]$} & {$[3.02]^{* * *}$} & {$[0.94]$} & {$[2.47]^{* * *}$} & {$[2.26]^{* *}$} \\
\hline \multirow[t]{2}{*}{$B M$} & 0.010 & -0.007 & 0.234 & 0.058 & 0.721 & 0.318 \\
\hline & {$[0.43]$} & {$[0.60]$} & {$[3.18]^{* * *}$} & {$[0.91]$} & {$[3.07] * * *$} & {$[2.36]^{* * *}$} \\
\hline \multirow[t]{2}{*}{ Cash } & 0.012 & 0.008 & -0.552 & -0.369 & 0.708 & 0.516 \\
\hline & {$[0.28]$} & {$[0.31]$} & {$[2.70] * * *$} & {$[3.27] * * *$} & {$[1.87]^{*}$} & {$[2.49] * * *$} \\
\hline \multirow[t]{2}{*}{ Sales Growth } & -0.030 & -0.016 & -0.314 & -0.119 & -0.202 & -0.088 \\
\hline & {$[1.82]^{*}$} & [1.48] & {$[4.49]^{* * *}$} & {$[2.84]^{* * *}$} & {$[1.72]^{*}$} & [1.19] \\
\hline Time FE & Yes & Yes & Yes & Yes & Yes & Yes \\
\hline Industry FE & Yes & Yes & Yes & Yes & Yes & Yes \\
\hline Adjusted $R^{2}$ & 0.23 & 0.17 & 0.42 & 0.31 & 0.41 & 0.34 \\
\hline$N$ & 8,762 & 8,762 & 8,762 & 8,762 & 8,762 & 8,762 \\
\hline
\end{tabular}


Table 7. Political Activism and Firm Value: Regulated vs. Non-Regulated Industries

This table shows the results from regressing announcement returns on measures of political activism for regulated and non-regulated industries. The dependent variable is expressed as the percentage CAR measured over different event windows where day 0 is January 21, 2010 when $C U$ is announced. Regulated is a dummy variable that equals one if SIC is between 4399 and 5001 and zero otherwise. Political activism variables are as in Table 2. The complete definitions of the control variables can be found in the appendix. We winsorize each control variable at percentiles 1 and 99. We include industry dummies based on three-digit SIC code and cluster standard errors by industry. $* * *, * *$, and * represent the $1 \%, 5 \%$, and $10 \%$ significance level, respectively.

\begin{tabular}{|c|c|c|c|c|}
\hline & \multicolumn{4}{|c|}{ Announcement Returns } \\
\hline & $(-1,+1)$ & $(0,+1)$ & $(-1,+2)$ & $(-1,+3)$ \\
\hline \multirow[t]{2}{*}{ Regulated } & 2.648 & 3.378 & 4.851 & 2.700 \\
\hline & {$[7.71]^{* * *}$} & {$[13.41]^{* * *}$} & {$[14.10]^{* * *}$} & {$[6.77] * * *$} \\
\hline \multirow{2}{*}{$\begin{array}{l}\text { Connection* } \\
\text { Regulated }\end{array}$} & 0.034 & 0.034 & 0.023 & 0.045 \\
\hline & {$[0.41]$} & {$[0.63]$} & {$[0.30]$} & {$[0.50]$} \\
\hline Connection* & -0.128 & -0.116 & -0.129 & -0.152 \\
\hline \multirow{3}{*}{$\begin{array}{l}\text { Non-Regulated } \\
\text { Lobbying }\end{array}$} & {$[3.22]^{* * *}$} & {$[2.45]^{* * *}$} & {$[2.60]^{* * *}$} & {$[2.81]^{* * *}$} \\
\hline & 0.020 & 0.005 & 0.020 & 0.027 \\
\hline & {$[1.04]$} & {$[0.38]$} & [1.02] & {$[1.37]$} \\
\hline \multirow{2}{*}{$\begin{array}{c}\text { Executive } \\
\text { Contribution }\end{array}$} & 0.040 & 0.042 & 0.030 & 0.050 \\
\hline & {$[0.98]$} & {$[1.06]$} & {$[0.67]$} & [1.12] \\
\hline \multirow[t]{2}{*}{ PAC Contribution } & -0.026 & -0.020 & -0.021 & -0.019 \\
\hline & {$[1.16]$} & {$[1.08]$} & {$[0.95]$} & {$[0.71]$} \\
\hline \multirow{2}{*}{$\begin{array}{l}\text { Institutional } \\
\text { Ownership }\end{array}$} & 0.524 & 0.848 & 0.743 & 0.858 \\
\hline & [1.11] & {$[1.92]^{*}$} & {$[1.55]$} & [1.59] \\
\hline \multirow[t]{2}{*}{ Size } & -0.035 & -0.113 & 0.072 & 0.177 \\
\hline & {$[0.30]$} & {$[1.31]$} & {$[0.65]$} & [1.18] \\
\hline \multirow[t]{2}{*}{$B M$} & 0.968 & 0.350 & 0.898 & 0.812 \\
\hline & {$[1.54]$} & {$[0.85]$} & [1.26] & [0.94] \\
\hline \multirow{2}{*}{ Past Return } & -5.577 & -2.087 & -8.810 & -8.788 \\
\hline & {$[1.27]$} & {$[0.66]$} & [1.64] & {$[1.35]$} \\
\hline \multirow[t]{2}{*}{$R O A$} & 0.513 & 0.673 & 0.400 & -0.966 \\
\hline & {$[0.34]$} & [0.49] & {$[0.28]$} & {$[0.51]$} \\
\hline \multirow[t]{2}{*}{ Debt } & 1.506 & 0.401 & 2.387 & 2.728 \\
\hline & {$[1.77]^{*}$} & {$[0.47]$} & {$[2.49] * * *$} & {$[2.46] * * *$} \\
\hline \multirow[t]{2}{*}{ Cash } & 1.329 & 0.144 & 1.447 & 1.559 \\
\hline & {$[1.21]$} & [0.19] & {$[1.25]$} & [1.37] \\
\hline \multirow[t]{2}{*}{ Sales Growth } & -1.685 & -1.325 & -1.772 & -0.969 \\
\hline & {$[2.42] * * *$} & {$[2.09]^{* *}$} & {$[2.37]^{* * *}$} & [1.07] \\
\hline Industry FE & Yes & Yes & Yes & Yes \\
\hline Adjusted $R^{2}$ & 0.27 & 0.19 & 0.22 & 0.18 \\
\hline$N$ & 1,722 & 1,722 & 1,722 & 1,722 \\
\hline
\end{tabular}


Appendix: Variable Definitions

Panel A: Measures of Political Activism
The number of political connections firms had with
government organizations at national, state, or local levels.
We count it as one political connection if an individual with
a political background currently holds a position in the firm
(as an executive or board member). We first collect raw
data $(125,797$ observations) from the BoardEx database.
We drop observations if the start and end date for
government or firm positions held by individuals are
missing. We also delete observations if individuals leave
the firm before joining the government. 60,294
observations remain after these criteria. The position each
holds in a firm varies each year (20,656 firm-individual
observations). For individuals with no more than two
observations, we create the earliest start/end year and the
latest start/end year for each individual to verify the
duration of an individual's stay in the firm. For individuals
that have three or more observations $(1,839$ firm-individual
matches), we manually check to identify whether the
individual holds a position each year. We then create the
number of political connections for each firm-year by
aggregating the number of connected individuals in the
same firm.

Source: BoardEx database

Lobbying For the event study analysis, we add up for each firm all past lobbying expenditures made before 2009 to calculate cumulative prior lobbying expenditures (Lobbying). Lobbying is the natural $\log$ of the sum of all previous corporate lobbying expenditures before the end of 2009. We also use lobbying expenditures in 2009 as an alternative variable with similar results. In the diff-in-diff analysis, we use each firm's current value of lobbying expenditures for each year from 2007 to 2012. Lobbying data are available on https://www.opensecrets.org/lobby/.

Source: Center for Responsive Politics 
Executive Contribution

PAC Contribution
For the event study analysis, we measure executives' political contributions at a firm in 2009 (Executive Contribution) by adding all past contributions made before the end of 2009 by current executives independently of their previous occupation. We also sum up contributions made by both current and past executives provided the contributions are made during the tenure as a top executive of the firm, and results are similar. For the diff-in-diff analysis, we use the current value of executive contributions for each firm and year from 2007 to 2012. Individual political contributions data are collected from the Federal Election Commission (FEC) and matched to ExecuComp names. In the end, $82 \%$ of matched results are based on employer names rather than zip codes. We also check the occupation of matched donors. The FEC records occupation since 2001 and the coverage has improved over time. In 2010, $80 \%$ of the matched donors have recorded occupation of 'executive', 'director', 'CEO', etc.

Source: ExecuComp \& FEC

For the event study analysis, PAC Contribution for each firm in 2009 is the natural $\log$ of the sum of all prior political contributions donated from corporate Political Action Committees (PACs) to state elections before the end of 2009. For the diff-in-diff analysis, we use the current value of PAC contributions for each firm and year from 2007 to 2012. PAC contributions data are available on http://www.followthemoney.org/.

Source: Follow The Money

\footnotetext{
Panel B: Corporate Governance G-Index

An equally-weighted index based on 24 governance provisions provided by the Investor Responsibility Research Center (IRRC) (Gompers, Ishii, and Metrick, 2003). IRRC covers between 1400 and 1800 firms depending on the year. All S\&P 500 firms are covered in IRRC. High $G$-Index indicates weak corporate governance. Source: IRRC \& RiskMetrics Database

E-Index

An entrenchment index based on six provisions: staggered boards, limits to shareholder bylaw amendments, poison pills, golden parachutes, and supermajority requirements for charter amendments and mergers (Bebchuk, Cohen, and
} 
Ferrell, 2009). High E-Index indicates weak corporate governance.

Source: RiskMetrics Database

Excesspay

The difference between CEO compensation and the median compensation of a set of peer firms of the same industry and similar size as that of the firm (Larcker, Ormazabal, and Taylor, 2011). More specifically, it is calculated as the natural logarithm of total compensation (variable TDC1 from ExecuComp) for the CEO less the natural logarithm of the median total annual pay for all remaining firms on ExecuComp that are in the same Fama and French (1997) 12 industry group and size quintile of the firm for the same year. High Excesspay indicates weak corporate governance.

Source: ExecuComp

CEO Duality

A binary variable that equals one if the CEO held the position of chairman of the board as of the end of each year and zero otherwise. If $C E O$ Duality equals one, it indicates weak corporate governance.

Source: RiskMetrics Database

Panel C: Financial Control Variables

Size

The natural $\log$ of the market value of equity (item $25 *$ item 24).

Source: Compustat

$B M$

The book value of equity (item 60) divided by market value of equity (item $25 *$ item 24 ).

Source: Compustat

Past Return

The past stock return for the previous twelve months.

Source: Center for Research in Securities Prices (CRSP) files

$R O A$

Ratio of operating income (item 13) to book assets (item 6).

Source: Compustat

Debt

Book value of debt (item $9+$ item 34) divided by book assets (item 6).

Source: Compustat 


\begin{abstract}
Cash Cash holdings (item 1) over book assets (item 6).
Source: Compustat

Leverage

Book value of debt (item 9+ item 34) divided by the sum of book value of debt (item 9+ item 34) and market value of equity (item $25^{*}$ item 24 ).

Source: Compustat

Tobin's $Q$

Sales Growth

The book value of assets (item 6) minus book value of equity (item144) plus the market value of equity (item $25^{*}$ item 24), all divided by book value of assets (item 6).

Source: Compustat

Investment

The difference between current sales (item 12) and lagged sales, all divided by lagged sales.

Source: Compustat

Capital expenditure (item 145) divided by book assets (item 6).

Source: Compustat

Institutional Ownership The sum of the holdings of all institutions domiciled in the US where the stock is listed divided by the firm's market capitalization.
\end{abstract}

Source: FactSet/LionShares Database 